\title{
A COMPARATIVE DESCRIPTIVE STUDY TO ASSESS THE AWARENESS REGARDING ANTENATAL DIET AMONG PREGNANT WOMEN AT SELECTED RURAL AND URBAN AREA OF JODHPUR
}

\author{
${ }^{1}$ Rohit Kumar Chouhan, ${ }^{2}$ Suresh \\ ${ }^{1}$ Community Health Officer, Govt. of Rajasthan \\ ${ }^{2}$ Lecturer, K.S. Memorial College of Nursing, Jodhpur
}

Article DOI: https://doi.org/10.36713/epra7814

DOI No: $10.36713 /$ epra7814

\begin{abstract}
INTRODUCTION: Good nutrition is an important part of leading a healthy lifestyle. It is essential for growth and development, health and wellbeing. Eating a healthy diet contributes to preventing future illness and improving the quality and length of life. Good nutrition means your body gets all the nutrients, vitamins, and minerals it needs to work its best. Plan your meals and snacks to include nutrient-dense foods that are also low in calories.

AIM OF THE STUDY: Assess the awareness regarding antenatal diet among pregnant women.

METERIAL AND METHOD: A descriptive non-experimental comparative study was carried out to assess the awareness of 100 pregnant women selected by purposive sampling, who were pregnant women in rural \& urban area in Jodhpur Rajasthan were assessed by using a structured knowledge questionnaire and analyzed by using descriptive and inferential statistics were used for data analysis.

RESULT: The finding showed that in rural area majority (64\%) of the pregnant women had below-average awareness, while in urban area majority (74\%) of the pregnant women had above-average awareness regarding antenatal diet. According to the different aspects of the antenatal diet the awareness score of both rural \& urban pregnant women was highest regarding the Micronutrient in diet. However, the majority of the demographic variable of the rural respondents such as age, religion, education status, monthly household, income, type of family, hazardous habits, number of children, source of information were found no significant association with the level of awareness except the number of gravida, where as in urban respondents such as age, religion, education status, monthly household, income, type of family, hazardous habits, number of gravida, number of children, were found no significant association with the level of awareness except the source of information.

CONCLUSION: It can be concluded that pregnant women in rural area majority (64\%) of the pregnant women had below-average awareness, while in urban area majority (74\%) of the pregnant women had above-average awareness regarding antenatal as per current research recommendations.
\end{abstract}

KEY WORDS: Awareness, antenatal diet, pregnant women, rural and urban area

\section{INTRODUCTION \& BACKGROUND OF THE STUDY}

Balanced nutrition during pregnancy is very important for mother and fetal well-being. Approximately 300 extra calories are needed daily to maintain a healthy pregnancy. These calories should come from a balanced diet of protein, fruits, vegetables, and whole grains, with sweets and fats, kept to a minimum. A healthy, well-balanced diet during pregnancy can also help to minimize some pregnancy symptoms such as nausea and constipation. Fluid intake is also an important part of healthy pregnancy nutrition. Women can take in enough fluids by drinking several glasses of water each day, in addition to the fluids in juices and soups. An expectant mother should talk with her health care provider or midwife about restricting her intake of caffeine and artificial sweeteners. All alcohol should be avoided in pregnancy

Poor maternal nutrition is the key factor contributing to poor fetal development, which increases the risk that the baby born will be ill or die. 


\section{EPRA International Journal of Research and Development (IJRD) \\ Volume: 6 | Issue: 7 | July 2021

\author{
- Peer Reviewed Journal
}

Research shows that maternal nutritional status during pregnancy plays a more important role in determining fetal health and predisposition to some diseases than genetic factors (e.g. a genetic predisposition to obesity)

Maternal nutrition during pregnancy also appears to have a "fetal programming" effect, that is, the fetus learns nutritional habits, which will influence it for the rest of its life before it is even born. A fetus will also adapt its metabolism and other body systems to cope with different states of nutrition. I.e. an under-nourished fetus, which does not receive enough macronutrients or energy, responds by reducing glucose and insulin production, which ultimately slows the rate of fetal growth and increases the risk of low birth weight. It may also alter the metabolism permanently and leave an individual predisposed to metabolic conditions such as diabetes. The fetus also adapts to under-nutrition by redirecting blood flow and therefore the supply of nutrients to protect the brain, at the expense of fully developing other organs including the kidneys, muscles and endocrine system (the system which regulates the body's hormone production)

Pregnant women's nutrition is crucial for good pregnancy outcomes and improving their children's nutritional status. The present study aimed to examine the level of awareness and knowledge towards maternal nutrition and dietary diversity practices among pregnant mothers in rural and urban areas.

Pregnant women had limited awareness and poor dietary diversity practices, they exhibited a relatively favorable attitude towards major nutritional recommendations. The use of antenatal diet and its follow up as a point of entry for educating pregnant women and increasing nutrition awareness and knowledge is recommended.

\section{OBJECTIVES OF THE STUDY}

- To assess the awareness regarding antenatal diet among pregnant women in the rural and urban areas.

- To compare the awareness regarding antenatal diet among pregnant women in the rural and urban areas.

- To find out the association between the awareness level regarding antenatal diet and selected sociodemographic variables among pregnant women in the rural and urban areas.

\section{HYPOTHESIS OF THE STUDY}

- $\quad \mathbf{H}_{1}$-There is a significant difference between awareness regarding antenatal diet among pregnant women in selected rural and urban areas at the level of $\square \leq 0.05$.

- $\mathbf{H}_{\mathbf{2}}-$ There is a significant association between the awareness level regarding antenatal diet and selected socio-demographic variables among pregnant women in a rural and urban area at the level of $\square \leq 0.05$.

\section{OPERATIONAL DEFINITION}

- Awareness -It refers to the knowledge of pregnant women regarding antenatal diet, which was measured through responses towards questionnaire prepared by the investigator

- Antenatal Diet -Referred to the food items taken by the women during pregnancy.

- Pregnant Women - It referred to the pregnant women who are attending the antenatal clinic at or after 12 weeks of gestation.

- Rural Areas - Rural areas located outside of the city and have less health and other facilities. and consist of less population. (>3000)

- Urban Area - Urban area are settlement where the population is very high and has the features of a built environment, high health and other facility and consist of high population. (>40000)

\section{ASSUMPTION}

- Pregnant women may have adequate awareness regarding antenatal diet.

\section{DELIMITATION}

The study is limited to the pregnant women of selected rural and urban areas of Jodhpur.

\section{RESEARCH METHODOLOGY}

- RESEARCH APPROACH

Quantitative research approach is considered appropriate for the present study.

\section{- RESEARCH DESIGN}

Descriptive non-experimental comparative study was adopted for this study.

\section{RESEARCH VARIABLE}

- Research Variable: Research variables are concept at various levels of abstraction that are measured, manipulated or controlled in the study. The research variable used for this study comprised awareness regarding the antenatal diet.

- Demographic Variable: The socio-demographic variable considered for this study were age, education level of participants type of family, occupation of the participants, monthly family income and religion of participants.

\section{POPULATION}

The target population for this study was pregnant women. 


\title{
EPRA International Journal of Research and Development (IJRD)
}

Volume: 6 | Issue: 7 | July 2021

\author{
- Peer Reviewed Journal
}

SAMPLING SIZE

In this study, the sample consists 100 pregnant (50

from the rural area and 50 from the urban area).

\section{SAMPLING TECHNIQUE}

Non-probability purposive sampling technique was used for this study.

\section{RELIABLITY OF THE TOOL}

The reliability was established by using spearman brown prophecy formula and it is found to be reliable $(\mathrm{r}=0.782)$.

\section{MAJOR FINDING OF THE STUDY}

Table 1 Depicted that of pregnant women participated in the study, Age 20-30 R (36, 72\%), U (44, 88\%), C (80, 80\%), Religion Hindu R (43, 72\%), U (38, 76\%), C (81, 81\%), Education Illiterate R (20, $40 \%)$, secondary U $(28,56 \%)$, C secondary $(42,42 \%)$, Family income 10,000-20,000 R (27, 54\%), U (25, $50 \%), \mathrm{C}(52,52 \%)$, Type of family joint $\mathrm{R}(29,58 \%)$, nuclear U $(41,82 \%)$, nuclear C $(62,62 \%)$, Health hazards tobacco R $(27,54 \%)$, none U $(34,68 \%)$, none $\mathrm{C}(57,57 \%)$, Number of gravid two gravid R (23, $46 \%), \mathrm{U}(26,52 \%), \mathrm{C}(49,49 \%)$, Number of children one child R (22,44\%), U (25, 50\%), C (47, 47\%), Source of information health care provide R $(31,62 \%)$, TV/Newspaper U $(21,42 \%)$, Health care provider C (47, 47\%). (NOTE: - R-Rural, U-Urban, CCombined)

Table 2 Depicted that in rural area majority (64\%) of the pregnant women had below-average awareness and $36 \%$ above average awareness, while in urban area majority $74 \%$ of the pregnant women had above average awareness and $26 \%$ had below-average awareness regarding antenatal diet.

Table 3 Depicted shows that the calculated $\mathrm{p}$ value for $\chi_{(1)}^{2}=14.586$ is 0.000 . Since the $\mathrm{p}$-value $(0.000)<\alpha(0.05)$, it shows that there is a significant difference between the level of awareness regarding antenatal diet among pregnant women of rural and urban areas.

Table: 1 Frequency and percentage distribution of demographic variables among pregnant women

\begin{tabular}{|c|c|c|c|c|c|c|}
\hline \multirow{3}{*}{$\begin{array}{l}\text { Demographic } \\
\text { variable }\end{array}$} & \multicolumn{6}{|c|}{ Respondents Groups } \\
\hline & \multicolumn{2}{|c|}{ Rural(n=50) } & \multicolumn{2}{|c|}{$\operatorname{Urban}(\mathbf{n}=\mathbf{5 0})$} & \multicolumn{2}{|c|}{ Combined(n=100) } \\
\hline & Frequency & Percentage & Frequency & Percentage & Frequency & Percentage \\
\hline Age & & & & & & \\
\hline Below 20 & 14 & $28 \%$ & 5 & $10 \%$ & 19 & $19 \%$ \\
\hline 20 to 30 & 36 & $72 \%$ & 44 & $88 \%$ & 80 & $80 \%$ \\
\hline 30 to 40 & 0 & $0 \%$ & 01 & $02 \%$ & 01 & $01 \%$ \\
\hline \multicolumn{7}{|l|}{ Religion } \\
\hline Hindu & 43 & $86 \%$ & 38 & $76 \%$ & 81 & $81 \%$ \\
\hline Muslim & 07 & $14 \%$ & 08 & $16 \%$ & 15 & $15 \%$ \\
\hline Christian & 0 & $0 \%$ & 01 & $02 \%$ & 01 & $01 \%$ \\
\hline Sikh & 0 & $0 \%$ & 03 & $06 \%$ & 03 & $03 \%$ \\
\hline \multicolumn{7}{|l|}{ Education } \\
\hline Illiterate & 20 & $40 \%$ & 1 & $2 \%$ & 21 & $21 \%$ \\
\hline Primary & 14 & $28 \%$ & 10 & $20 \%$ & 24 & $24 \%$ \\
\hline Secondary & 14 & $28 \%$ & 28 & $56 \%$ & 42 & $42 \%$ \\
\hline Higher & 2 & $4 \%$ & 11 & $22 \%$ & 13 & $13 \%$ \\
\hline \multicolumn{7}{|l|}{ Family Income } \\
\hline Up to ₹ 5000 & 01 & $02 \%$ & 01 & $02 \%$ & 02 & $02 \%$ \\
\hline 5000 to 10000 & 09 & $18 \%$ & 04 & $08 \%$ & 13 & $13 \%$ \\
\hline $10000-20000$ & 27 & $54 \%$ & 25 & $50 \%$ & 52 & $52 \%$ \\
\hline Above ₹ 20000 & 13 & $26 \%$ & 20 & $40 \%$ & 33 & $33 \%$ \\
\hline \multicolumn{7}{|l|}{ Type of family } \\
\hline Nuclear & 21 & $42 \%$ & 41 & $82 \%$ & 62 & $62 \%$ \\
\hline Joint & 29 & $58 \%$ & 09 & $18 \%$ & 38 & $38 \%$ \\
\hline Extended & 0 & $0 \%$ & 0 & $0 \%$ & 0 & $0 \%$ \\
\hline
\end{tabular}




\section{EPRA International Journal of Research and Development (IJRD)}

Volume: 6 | Issue: 7 | July 2021

- Peer Reviewed Journal

\begin{tabular}{|c|c|c|c|c|c|c|}
\hline Health Hazard & & & & & & \\
\hline $\begin{array}{l}\text { Tobacco } \\
\text { Cigarette } \\
\text { Both } \\
\text { None }\end{array}$ & $\begin{array}{c}27 \\
0 \\
0 \\
23\end{array}$ & $\begin{array}{l}54 \% \\
0 \% \\
0 \% \\
46 \%\end{array}$ & $\begin{array}{c}15 \\
01 \\
0 \\
34\end{array}$ & $\begin{array}{c}30 \% \\
02 \% \\
0 \% \\
68 \%\end{array}$ & $\begin{array}{c}42 \\
01 \\
0 \\
57\end{array}$ & $\begin{array}{c}42 \% \\
01 \% \\
0 \% \\
57 \%\end{array}$ \\
\hline \multicolumn{7}{|l|}{$\begin{array}{c}\text { Number of } \\
\text { Gravid }\end{array}$} \\
\hline $\begin{array}{c}\text { One gravid } \\
\text { Two gravid } \\
\text { Three gravid } \\
\text { More than three }\end{array}$ & $\begin{array}{c}11 \\
23 \\
16 \\
0\end{array}$ & $\begin{array}{c}22 \% \\
46 \% \\
32 \% \\
0 \%\end{array}$ & $\begin{array}{l}15 \\
26 \\
07 \\
02\end{array}$ & $\begin{array}{l}30 \% \\
52 \% \\
14 \% \\
04 \%\end{array}$ & $\begin{array}{l}26 \\
49 \\
23 \\
02\end{array}$ & $\begin{array}{l}26 \% \\
49 \% \\
23 \% \\
02 \%\end{array}$ \\
\hline \multicolumn{7}{|l|}{$\begin{array}{c}\text { Number of } \\
\text { Children }\end{array}$} \\
\hline $\begin{array}{c}\text { No Child } \\
\text { One Child } \\
\text { Two Child } \\
\text { More than Two }\end{array}$ & $\begin{array}{l}13 \\
22 \\
14 \\
01\end{array}$ & $\begin{array}{l}26 \% \\
44 \% \\
28 \% \\
02 \%\end{array}$ & $\begin{array}{l}16 \\
25 \\
05 \\
04\end{array}$ & $\begin{array}{l}32 \% \\
50 \% \\
10 \% \\
08 \%\end{array}$ & $\begin{array}{l}29 \\
47 \\
19 \\
05\end{array}$ & $\begin{array}{l}29 \% \\
47 \% \\
19 \% \\
05 \%\end{array}$ \\
\hline \multicolumn{7}{|l|}{$\begin{array}{c}\text { Source of } \\
\text { Information }\end{array}$} \\
\hline $\begin{array}{l}\text { TV/newspaper } \\
\text { Health service } \\
\text { provider } \\
\text { Family/friends }\end{array}$ & $\begin{array}{l}05 \\
31 \\
14\end{array}$ & $\begin{array}{l}10 \% \\
62 \% \\
28 \%\end{array}$ & $\begin{array}{l}21 \\
16 \\
13\end{array}$ & $\begin{array}{l}42 \% \\
32 \% \\
26 \%\end{array}$ & $\begin{array}{l}26 \\
47 \\
27\end{array}$ & $\begin{array}{l}26 \% \\
47 \% \\
27 \%\end{array}$ \\
\hline
\end{tabular}

Table - 2: Frequency and percentage distribution of pregnant women by their level of awareness regarding antenatal diet in rural and urban areas.

\begin{tabular}{|l|c|c|c|c|c|c|}
\hline \multirow{2}{*}{ Awareness Level } & \multicolumn{3}{|c|}{ Respondents Groups } \\
\cline { 2 - 7 } & \multicolumn{2}{|c|}{$\begin{array}{c}\text { Rural } \\
(\mathbf{n = 5 0})\end{array}$} & \multicolumn{2}{c|}{$\begin{array}{c}\text { Urban } \\
(\mathbf{n = 5 0 )}\end{array}$} & \multicolumn{2}{c|}{$\begin{array}{l}\text { Combined } \\
(\mathbf{n = 1 0 0})\end{array}$} \\
\cline { 2 - 7 } & Frequency & Percentage & Frequency & Percentage & Frequency & Percentage \\
\hline Below Average & 32 & $64 \%$ & 13 & $26 \%$ & 45 & $45 \%$ \\
\hline Above Average & 18 & $36 \%$ & 37 & $74 \%$ & 55 & $55 \%$ \\
\hline
\end{tabular}

Table - 3: Association between the level of awareness regarding antenatal diet among pregnant women of the rural and urban areas.

\begin{tabular}{|c|c|c|c|c|}
\hline & & & $(\mathrm{N}=100)$ & \\
\hline \multirow{2}{*}{ Awareness Level } & \multicolumn{2}{|c|}{ Respondents Groups } & \multirow{2}{*}{ Chi Squire } & \multirow{2}{*}{ Inference } \\
\hline & $\begin{array}{r}\text { Rural } \\
(n=50)\end{array}$ & $\begin{array}{l}\text { Urban } \\
(n=50)\end{array}$ & & \\
\hline Below Average & 32 & 13 & \multirow{2}{*}{$\begin{array}{c}\chi^{2}=14.586 \\
d f=1 \\
p=0.000\end{array}$} & \multirow{2}{*}{$\begin{array}{c}\text { Significant a } \\
\mathrm{p} \leq 0.05\end{array}$} \\
\hline Above Average & 18 & 37 & & \\
\hline
\end{tabular}

\section{DISCUSSION}

The finding showed that in rural area majority $(64 \%)$ of the pregnant women had below-average awareness with mean 14.42 SD 5.055, while in urban area majority (74\%) of the pregnant women had above- average awareness with mean 8.3SD 3.699 regarding antenatal diet. According to the different aspects of the antenatal diet the awareness score of both rural \& urban pregnant women was highest regarding the Micronutrient in diet. 


\section{EPRA International Journal of Research and Development (IJRD) \\ Volume: 6 | Issue: 7 | July 2021 \\ - Peer Reviewed Journal}

However, the majority of the demographic variable of the rural respondents such as age, religion, education status, monthly household, income, type of family, hazardous habits, number of children, source of information were found no significant association with the level of awareness except the number of gravida, where as in urban respondents such as age, religion, education status, monthly household, income, type of family, hazardous habits, number of gravida, number of children, were found no significant association with the level of awareness except the source of information at the level of $p \square 0.05$ level.

\section{CONCLUSION}

The finding raised concern about all aspects of antenatal diet. A considerable below average in rural and above average in urban. The awareness in the urban area is more as compared to the rural area Therefore, the difference between awareness scores regarding antenatal diet among pregnant women of rural and urban areas is to be significantly different at the level of $\mathrm{p} \leq 0.05$.

\section{REFERENCES}

1. X.Z. Lim, L.J.Wong, Y.P.Lim, 2018 knowledge of nutrition during pregnancy and associated factors among antenatal mother. Int. J.P.H.CS. Vol. 5, $\begin{array}{lll}\text { P.No. } & 117 & -\end{array}$ https://www.researchgate.net/publication/32394159 5

2. S. Sindhu, D.Vidhya, K. Sivankumar, 2017 A study to assess the awareness and knowledge about the maternal nutrition. Int. J reprod contracept obstet gynecology (vol. 06$)\left(\begin{array}{lllll}253 & 2 & - & 35\end{array}\right)$ http://dx.doi.org/10.18203/2320-

1770.ijrcog20172346

3. Sunil S, ghanashyam S, lalkaji 2017 Knowledge on dietary patterns among pregnant women attending antenatal care check up Narayani hospital, Nepal. Int J Community Med Public Health. (vol. 04) $(1466-72)$

4. kolosova M, miskova 2017 A. Nutritional awareness among pregnant women in Latvia. Int $J$ Reprod Contracept Obstet Gynecol. (vol. 06) (2711-15)

https://www.researchgate.net/publication/31791086 6

5. PJ. Kavitha mole. 2017 A study to assess the knowledge and attitude regarding antenatal diet among Primigravida Mothers in selected Hospital, Payyanur Int. J advanced S R, () (vol.02) (06-11) www.allscientificjournal.com

6. Adikari AMNT, Sivakanesan. 2016 Assessment of nutritional status of pregnant women in a rural area in Sri Lanka. Tropical Agricultural Research Vol. $27 \quad$ (2): $203 \quad-211 \quad$ (). https://www.researchgate.net/publication/30551602 5

7. Sarkar PR, Haque Md. 2015 M. Awareness and Practices on Diet, Weight Management an Antenatal Care among Rural Pregnant Women. Int. J Nutri food sci. vol.(01) (01-04)

8. Tanha FD, Zadeh MG, 2013 The effects of healthy diet in pregnancy. $J$ family report health 7 (3) 121 $-125$

9. Swathi $N$, Priyanka D, Seeta M, Sonika R, Rashmi $R$, Vivek $R, 2017$ Knowledge of primigravida mothers on antenatal nutrition. Asian Pacific Journal of Health Sciences | Vol. 4 |12 - 14 | www.apjhs.com 